\title{
Biodiesel Production from Wet Spirulina sp. by One-Step Extraction-Transesterification
}

\author{
Yano Surya Pradana ${ }^{1,2, *}$, Fariz Azwar Azmi ${ }^{1}$,Wildan Masruri ${ }^{1}$ and Muhamad Hartono ${ }^{3}$ \\ ${ }^{1}$ Chemical Engineering Department, Faculty of Engineering, Universitas Gadjah Mada, Jalan Grafika No. 2, Yogyakarta 55281, \\ Indonesia \\ ${ }^{2}$ Center for Energy Studies, Universitas Gadjah Mada, SekipK-1A, Yogyakarta 55281, Indonesia \\ ${ }^{3}$ Chemical Engineering Department, Faculty of Applied Sciences, Delft University of Technology, Mekelweg 2, 2628 CD Delft, \\ Netherlands
}

\begin{abstract}
Microalgae has gained immense interests as the raw material for biofuel production. The lipid content in microalgae can be converted into biodiesel through conventional method which involves separated process of extraction and transesterification. In this study, the production of biodiesel from Spirulina sp. was performed through one-step extraction-transesterification using $\mathrm{KOH}$ as base catalyst to simplify the production of biodiesel. The mixture of methanol-hexane was employed as both solvent and reactant in the process. The resulting biodiesel was found to be mainly composed of methyl oleate and methyl palmitate. On the other hand, increasing the reaction temperature and reducing the quantity of methanol in solvent mixture would also increase the yield of biodiesel. The optimum methanol-hexane volumetric ratio and temperature which gave the highest biodiesel yield were $3: 7$ and $50^{\circ} \mathrm{C}$, respectively.
\end{abstract}

\section{Intoduction}

The proliferating growth of population followed by the rapid development of technology has resulted in an increase in energy demand from industrial sector, transportation, to household [1]. Until now, the nonrenewable fossil fuel has been opted as the main source of energy in many parts of the world with the limitation in availability [2]. The increasing demand which does not correspond with the depleting fossil fuel resources has promoted many attempts to develop renewable energy sources [3]. In the recent years, the search for alternative fuel is growing quite rapidly. This new and renewable energy search is not only intended to reduce dependence on fossil fuels but also to reduce greenhouse gas emissions [4]. One of the alternative renewable energy sources is derived from biomass or commonly referred to as biofuel [5]. Agricultural products such as corn, soybeans, and cassava can be used to produce biofuels such as bioethanol and biodiesel. However, the use of agricultural products in the manufacture of biofuels raises several problems as it can increase global food prices and cause damage to the soil nutrient cycle [6]. Hence, new raw materials for biofuel production are vastly required.

Microalgae is one of the most potent raw materials for biofuel development [7]. These unicellular species contain fat, carbohydrates, proteins and other compounds that can be utilized to produce biodiesel through extraction and transesterification processes [8]. Microalgae have several advantages over other biomasses such as higher photosynthetic efficiency, higher biomass production and rapid growth, high lipid content, and do not require large areas to breed [9]. By those advantages, microalgae are suitable as agent for accelerating the growth rate of fish, which is the similar effect of micro bubble generator application in fish farming [10]. Moreover, microalgae can be used to produce several renewable fuels such as biodiesel, bioethanol, biohydrogen, methane, and syn-gas as presented in Fig. 1 [11].

Among the option as seen in Fig. 1, the conversion of microalgae biomass into biodiesel seems attractive. Biodiesel is a mono-alkyl ester of long chain fatty acids from conventional and non-conventional animal oils and fats [12]. Biodiesel has several advantages compared to petro-diesel as it is renewable, non-carcinogenic and nonmutagenic, biodegradable, soluble in petroleum diesel, lubricating ability, high cetane number and absence of aromatic compounds [13]. Biodiesel can also reduce emissions of carbon monoxide (CO), hydrocarbons ( $\mathrm{HC}$ ), and particulates in waste gas compared to diesel petroleum, thus benefiting the environment $[14 ; 15]$. Biodiesel production from microalgae is usually carried out in two stages. In the first stage, microalgae are extracted by mechanical and chemical means. Subsequently, the microalgae oil undergoes transesterification with alcohol with the aid of an acid or base catalyst to form biodiesel and glycerol as a byproduct [16]. The base catalyst is often used to increase reaction rate. Moreover, the conversion is higher than when using an acid catalyst [17].

\footnotetext{
${ }^{*}$ Corresponding author: yanopradana@ugm.ac.id
} 


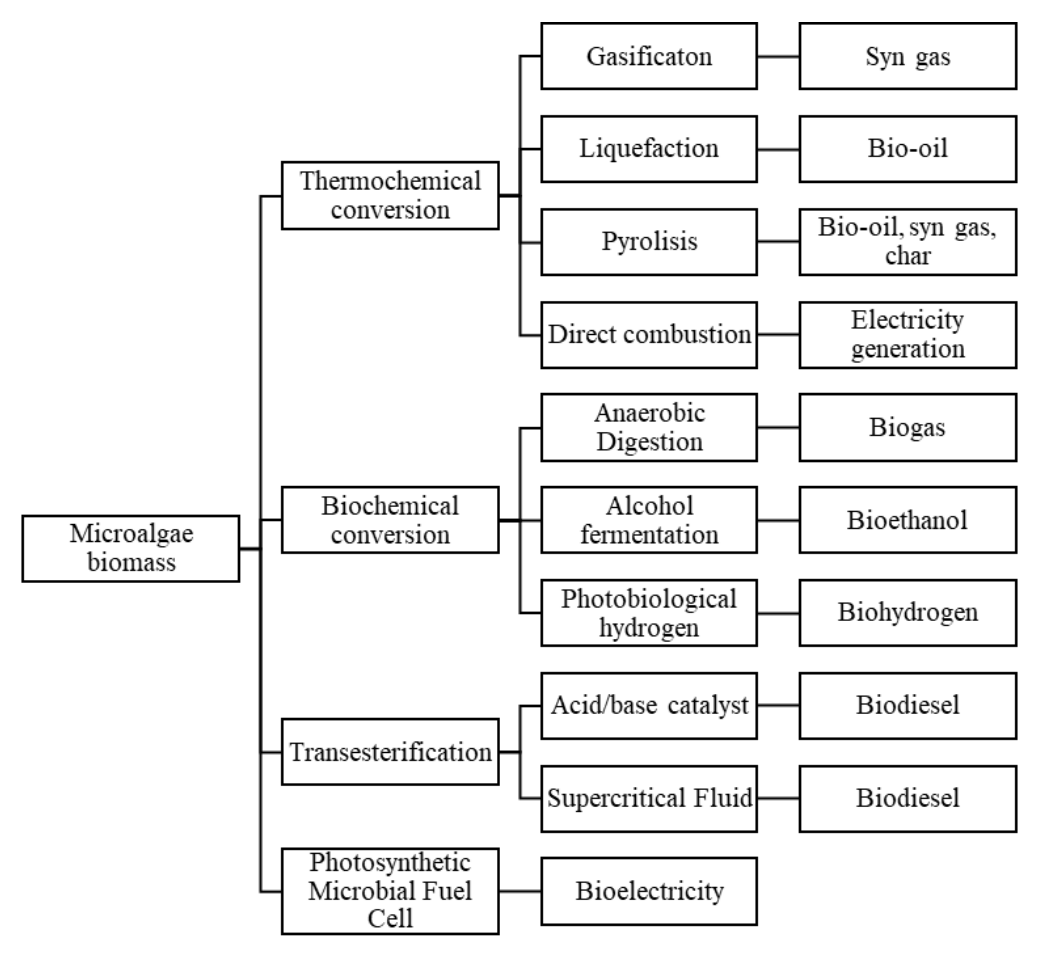

Fig. 1. Framework of microalgae biomass utilization as renewable energy source [10]

In this study, biodiesel is produced from microalgae through a single stage extraction and transesterification process using methanol-hexane mixture. The process employed in this study reduces the number of steps in the preparation of biodiesel in the conventional method, that is by removing the extraction step and that the extracted oil is in direct contact with the alcohol. Hence, alcohol acts both as a solvent and reactant. By using fewer steps, the production of biodiesel using this process will simplify the biodiesel manufacturing process and reduces the manufacturing cost [18].

\section{Materials and Methods}

\subsection{Materials}

Spirulina sp. used as raw material was originated from Lamongan, East Java. Methanol $\left(\mathrm{CH}_{3} \mathrm{OH}\right)$ used as a solvent and reactant in biodiesel synthesis reaction was purchased from CV. General Labora, Yogyakarta. Hexane $\left(\mathrm{C}_{6} \mathrm{H}_{14}\right)$ used as a solvent and potassium hydroxide $(\mathrm{KOH})$ used as a base catalyst was also purchased from CV. General Labora, Yogyakarta.

\subsection{Biodiesel synthesis}

Spirulina sp., as much as $150 \mathrm{~g}$, were weighed using digital analytical balance. Methanol and hexane of $500 \mathrm{~mL}$ were prepared, with a methanol-hexane volumetric ratio of 1: 1 . As much as $0.2 \mathrm{~g}$ of $\mathrm{KOH}$ catalyst was dissolved with prepared methanol. Methanol, KOH, and hexane which have been prepared were put into a three-necked flask. Microalgae were then also put into a three-neck flask. The cooling water stream and stirrer were switched on and set at $800 \mathrm{rpm}$. Heater stove was set to the reaction temperature of $45^{\circ} \mathrm{C}$. After 2 hours of running, the mixture was cooled to room temperature and then filtered to separate the filtrate from the formed cake. The filtrate, which comprised of 2 layers of glycerol at the bottom and biodiesel at the top layer was evaporated to recover methanol and hexane.

A similar procedure was repeated with reaction temperature of 35 and $50^{\circ} \mathrm{C}$ and a variation of methanolhexane volumetric ratio of $3: 7$ and 7:3 as with a fixed solvent volume of $500 \mathrm{~mL}$.

\subsection{Data analysis}

Yield of biodiesel was calculated by using Equation (1).

$$
\text { Yield }(\%)=\frac{\mathrm{mb}}{\mathrm{mm}} \times 100 \%
$$

Where $m b$ denotes mass of biodiesel (gram) and $m m$ denotes mass of microalgae (gram). Methyl ester component in biodiesel from Spirulina sp. was analysed by using GC-MS to determine the constituent compounds.

\section{Results and discussion}

The determination of fatty acid present in biodiesel derived from Spirulina $s p$. is a very important parameter to determine since it can define the properties of biodiesel such as molecular weight and cetane number $(\mathrm{CN})$. The result of GC-MS analysis of the biodiesel produced from Spirulina sp. is presented in Fig. 2 and Table 1. It can be seen that biodiesel derived from microalgae mainly composed of methyl oleate with a percentage of $45.10 \%$, 
followed by methyl palmitate and significantly lower percentage of methyl linoleate and methyl stearate.

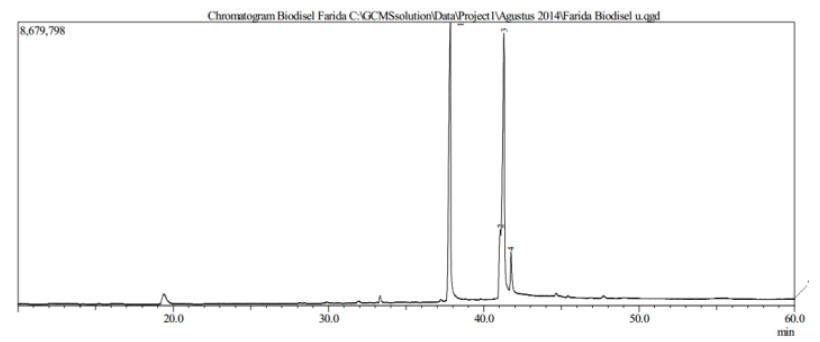

Fig. 2. Result of GC-MS analysis of biodiesel derived from Spirulina $s p$.

Table 1. Fatty acid composition of biodiesel derived from Spirulina $s p$.

\begin{tabular}{|c|c|c|}
\hline Component & Chemical formula & Yield (\%) \\
\hline Methyl Palmitat & $\mathrm{C}_{17} \mathrm{H}_{34} \mathrm{O}_{2}$ & 41.03 \\
\hline Methyl Linoleate & $\mathrm{C}_{19} \mathrm{H}_{34} \mathrm{O}_{2}$ & 8.34 \\
\hline Methyl Oleate & $\mathrm{C}_{19} \mathrm{H}_{36} \mathrm{O}_{2}$ & 45.10 \\
\hline Methyl Stearate & $\mathrm{C}_{19} \mathrm{H}_{38} \mathrm{O}_{2}$ & 5.54 \\
\hline
\end{tabular}

Methyl oleate has been used to enrich biodiesel fuels as it can improve biodiesel properties [19;20]. Moreover, Knothe [21] found that the $\mathrm{CN}$ of methyl oleate exceeds the minimum standard value in ASTM D6751. The presence of methyl oleate as fatty acid in biodiesel has been shown to reduce regulated hydrocarbon as well as $\mathrm{CO}$ emission compared to the other fatty acid methyl ester. However, further studies are required to test the quality and properties of the resulting biodiesel from Spirulina $s p$.

\subsection{Effect of methanol-hexane volumetric ratio}

The effect of methanol-hexane volumetric ratio on biodiesel yield is presented in Table 2 .

Table 2. Effect of methanol-hexane volumetric ratio on biodiesel yield

\begin{tabular}{|c|c|}
\hline $\begin{array}{c}\text { Methanol-hexane } \\
\text { volumeric ratio }\end{array}$ & Yield (\%) \\
\hline $3: 7$ & 0.5730 \\
\hline $1: 1$ & 0.5728 \\
\hline $7: 3$ & 0.5726 \\
\hline
\end{tabular}

Table 2 shows that the higher amount of methanol added to the methanol-hexane mixture as the solvent decreased the yield of biodiesel, although insignificantly with an order of $10^{-4}$. The decline in biodiesel yield is due to the decline of the microalgae oil extracted by the solvent. Non-polar oils are more prone to be extracted by solvents that have the same polarity (like dissolve like) that, in this case, is by hexane. The solvent mixture with higher hexane fraction extracted more oil, which then reacted with methanol. Methanol is not effective as a solvent because it is a polar compound so that it cannot extract microalga oil as efficient as hexane. Hence, the addition of hexane which is a non-polar compound as cosolvent can increase the mass transfer of oil from microalga to solvent mixture [22].

\subsection{Effect of reaction temperature}

Table 3 presents the result of reaction temperature variations on biodiesel yield. As the process temperature rose, the biodiesel yield would also rise. The highest biodiesel yield of $0.6870 \%$ was achieved at $50^{\circ} \mathrm{C}$. The increase in yield can be ascribed to higher oil temperatures which allowed solvents to extract more oil. In addition, higher temperatures would also increase the interaction between reactants [18]. However, the temperature was limited to $50^{\circ} \mathrm{C}$ for the safety of experiment.

Table 3. Effect of reaction temperature on biodiesel yield

\begin{tabular}{|c|c|}
\hline $\begin{array}{c}\text { Reaction } \\
\text { temperature, }\end{array}{ }^{\mathbf{o}} \mathbf{C}$ & Yield (\%) \\
\hline 35 & 0.5727 \\
\hline 45 & 0.5728 \\
\hline 50 & 0.6780 \\
\hline
\end{tabular}

\section{Conclusions}

One-step extraction-transesterification of Spirulina $s p$. using methanol-hexane mixture was able to simplify the production of biodiesel. Methyl oleate and methyl palmitate was found to be the main components of biodiesel derived from Spirulina sp. The use of hexane as co-solvent in extraction-transesterification was able to improve the extraction of algal oil hence increasing biodiesel yield. Increasing the quantity of methanol in the solvent mixture reduced the yield of biodiesel. However, increasing the reaction temperature would increase the biodiesel yield. The optimum methanol-hexane volumetric ratio and temperature which gave the highest biodiesel yield were $3: 7$ and $50^{\circ} \mathrm{C}$, respectively.

The authors would like to thank Prof.Arief Budiman for providing suggestion in this study and Chemical Engineering Department, Faculty of Engineering, Universitas Gadjah Mada, Indonesia for financial support through Research Grant No. 451s/H1.17TK/PL/2017.

\section{References}

1. Y.S. Pradana, A. Hidayat, A. Prasetya, A. Budiman, Defect Diffus. Forum 382, 280-285 (2018).

2. Y.S. Pradana, Y. Kusumastuti, F.N. Rahma, N. Effendy, Chem. Eng. Trans. 56, 1549-1554 (2017).

3. S.S.M. Mostafa, N.Sh. El-Gendy, Arab. J. Chem. 10 (2), S2040-S2050 (2013).

4. M.B. Tasic, L.F.R. Pinto, B.C. Klein, V.B. Veljkovic, R.M. Filho, Renew. Sust. Energ. Rev. 64, 260-270 (2016).

5. T.M. Mata, A.A. Martins, N.S. Caetano, Renew. Sust. Energ. Rev. 14, 217-232 (2010).

6. G.A. Nafis, P.Y. Mumpuni, Indarto, A. Budiman, 
AIP Conference Proceedings 1699, Art. No. 030021 (2015).

7. E.A. Ehimen, Z.F. Sun, C.G. Carrington, Fuel 89, 677-684 (2010).

8. Y.S. Pradana, H. Sudibyo, E.A. Suyono, Indarto, A. Budiman, Energy Procedia 105, 277-282 (2017).

9. H. Sudibyo, Y.S. Pradana, T.T. Samudra, A. Budiman, Indarto, E.A. Suyono, Energy Procedia 105, 270-276 (2017).

10. W. Budhijanto, D. Darlianto, Y.S. Pradana, M. Hartono, AIP Conference Proceedings 1840, Art. No. 110008 (2017).

11. H.T. Chung, L.S. Pau, C. Jo-Shu, C.L. Tau, C.L. John, Biotechnol. Adv. 33, 1219-1227 (2010).

12. G. Knothe, J. Krahl, J. Van Gerpe, The Biodiesel Handbook (American Oil Chemist's Society (AOCS) Press, Urbana, 2005).

13. D.R.Sawitri,Sutijan, A. Budiman, ARPN Journal of Engineering and Applied Sciences, 11 (16), 99519957.

14. G. Knothe, Fuel Process. Technol. 86, 1059-1070 (2005).

15. M. Lapuerta, O. Armas, J. Rodriguez-Fernandez, Prog. Energy Combust. Sci. 34, 198-223 (2008).

16. R. Zakaria, A.P. Harvey, Fuel Process. Technol. 10, 53-60 (2012).

17. G.H. Huang, F. Chen, D. Wei, X.W. Zhang, G. Chen, Appl. Energy 87, 38-46 (2010).

18. P. Nautiyal, K.A. Subramanian, M.G. Dastidar, Fuel 135, 228-234 (2014).

19. N.A. Bringe, The Biodiesel Handbook (AOCS Press: Champaign, IL, 2005).

20. A.J. Kinney, T.E. Clemente, Fuel Process. Technol. 86, 1137-1147 (2005).

21. G. Knothe, Energ Fuel 22, 1358-1364 (2008).

22. I.A. Kartika, M. Yani, D. Ariono, Ph. Evon, L. Rigal, Fuel 106, 111-117 (2013). 